\title{
Cash Holdings, Dividend Policy, and Stock Return of the Automobile Related Firms at the Tokyo Stock Exchange: Before and After the US Lehman Shock
}

\author{
Chikashi Tsuji \\ Faculty of Economics, Chuo University, \\ 742-1 Higashinakano Hachioji-shi, Tokyo 192-0393, Japan \\ E-mail: mail_sec_low@minos.ocn.ne.jp
}

Received: December 24, 2013 Accepted: January 7, 2014 Published: February 11, 2014

doi:10.5296/jsss.v1i2.5100 URL: http://dx.doi.org/10.5296/jsss.v1i2.5100

\begin{abstract}
This paper explores the linkage among cash holdings, dividend policies, and stock returns of the automobile related firms at the Tokyo Stock Exchange by employing the panel data analyses. In addition, our research focuses on the two periods: before and after the US Lehman shock. The main findings of our study are as follows. First, 1) before the US Lehman shock, only the internal reserves to total asset ratio is negatively related with the one-year future stock return. Differently from this, 2) after the US Lehman shock, not only the internal reserves to total asset ratio, but also the cash holdings to total asset ratio, the payout ratio, and the plowback ratio are statistically significantly related with the one-year future stock returns.

Keywords: Dividend Policy, Lehman Shock, Japanese Automobile Related Firms, Panel Data Analysis
\end{abstract}




\section{Introduction}

The dividend policy and the firm cash holdings are important for the future corporate market values in the US as Pinkowitz et al. (2006) and Faulkender and Wang (2006) evidenced. After the US Lehman shock, even the well-known Japanese leading companies such as Toyota and Honda suffer from the difficult economic condition. How are the market valuations in the Japanese automobile related firms including Toyota and Honda before and after the Lehman shock? Further, how are their states of cash holdings and dividend policies evaluated in stock markets before and after the US Lehman shock?

To answer these questions, we focus on the automobile related firms at the Tokyo Stock Exchange (TSE) in Japan, and examine the market valuations of their states of cash holdings and dividend policies before and after the US Lehman shock. These are the objectives of this paper. The interesting findings of this study are as follows. First, 1) before the US Lehman shock, only the internal reserves to total asset ratio is negatively related with their one-year future stock returns. Second, 2) after the Lehman shock, the cash to total asset ratio, the internal reserves to total asset ratio, the payout ratio, and the plowback ratio are statistically significantly related with their one-year future stock returns. The rest of this article is organized as follows. Section 2 reviews the related existing literature with our study, Section 3 explains our data, Section 4 documents our research methodology, Section 5 overviews the relations among the variables interested in this paper, Section 6 supplies our empirical results, and Section 7 concludes the paper.

\section{Literature Review}

This section reviews the related existing literature. The famous classic by Modigliani and Miller (1961) proved that the dividend policy and the firm value are irrelevant. On the other hand, the notable study by Jensen (1986) argued that when firms have larger amount of surplus cash, payout is an effective way to reduce the agency costs between corporate managers and shareholders. According to this suggestion, the evaluation of the corporate payout would depend on the state of the firm.

Further, Pinkowitz et al. (2006) suggested that in the countries where investor protections are weak, payout was more highly evaluated than cash accumulation. Faulkender and Wang (2006) argued that cash holdings were evaluated more in firms that repurchased their own shares than in firms that implemented dividend payouts. Moreover, Harford et al. (2008) discussed that in firms under appropriate corporate governance, high cash holdings were positively related with dividends. Finally, Al-Najjar and Belghitar (2011) concluded that after their empirical analyses, the linkage between cash holdings and dividends was unclear.

As above literature review implies, it is difficult to find the empirical study that simultaneously analyzed the two issues of our focus: 1) the linkage between the Japanese automobile related firms' cash holdings and their future stock returns and 2) the linkage between the automobile related firms' dividend policies and their future stock returns. Thus, by using the Japanese data, we newly perform our empirical analyses regarding the above two matters by focusing on the two periods: before and after the US Lehman shock. 


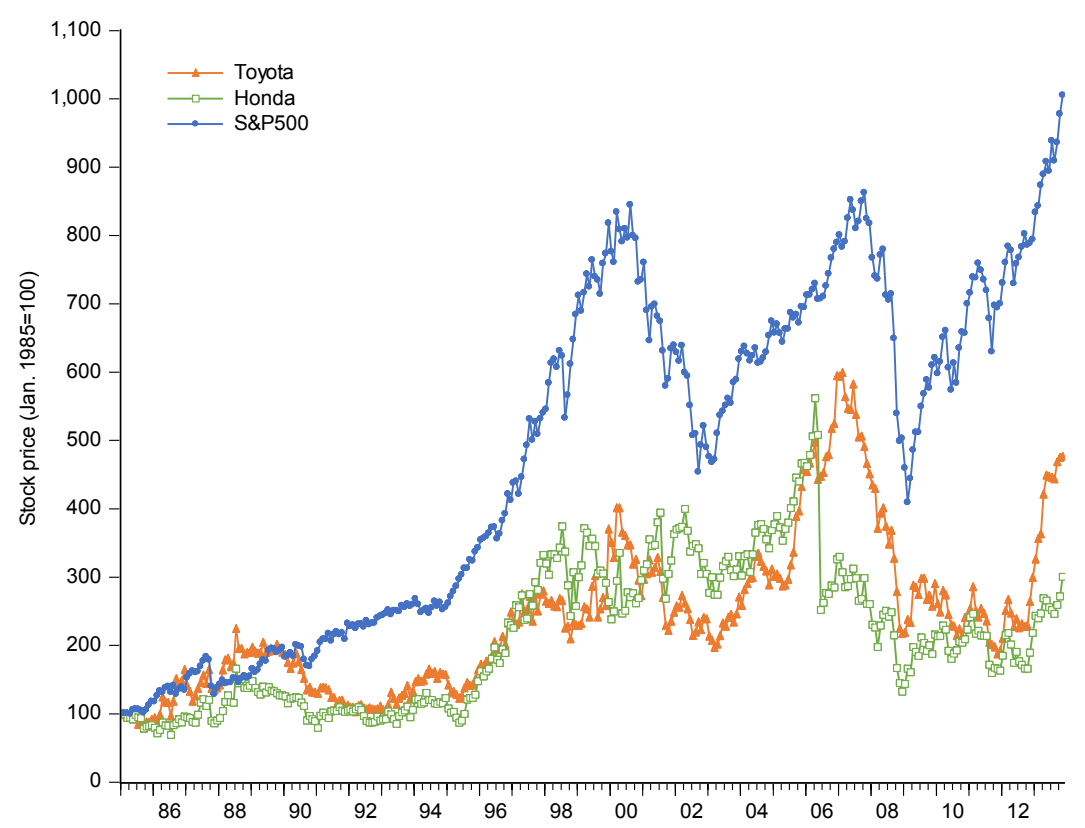

Figure 1. Stock Price Dynamics of the US Markets and the Japanese Representative Automobile Firms: Time-series Evolution from January 1985 to November 2013

Notes: This figure exhibits the time-series dynamics of the price of the S\&P 500 in the US and the stock prices of the Japanese representative automobile companies, Toyota and Honda. In this figure, all prices are adjusted so that those in January 1985 equal to 100. The price data are from January 1985 to November 2013.

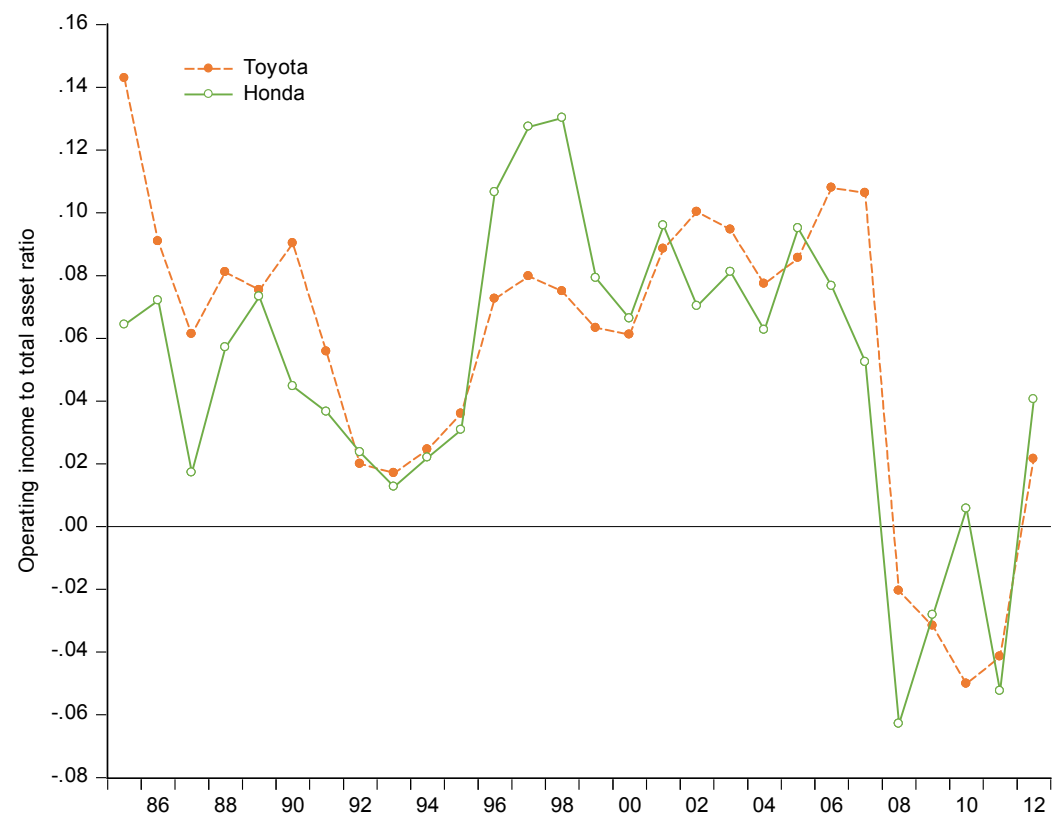

Figure 2. Time-series Dynamics of the Operating Income to Total Asset Ratios: The Cases of the Representative Automobile Firms in Japan

Notes: This figure shows the time-series dynamics of the operating income to total asset ratios of the Japanese representative automobile companies, Toyota and Honda. In this figure, the time-series of the operating income to total asset ratios of two firms are from the fiscal year of 1985 to 2012 . 


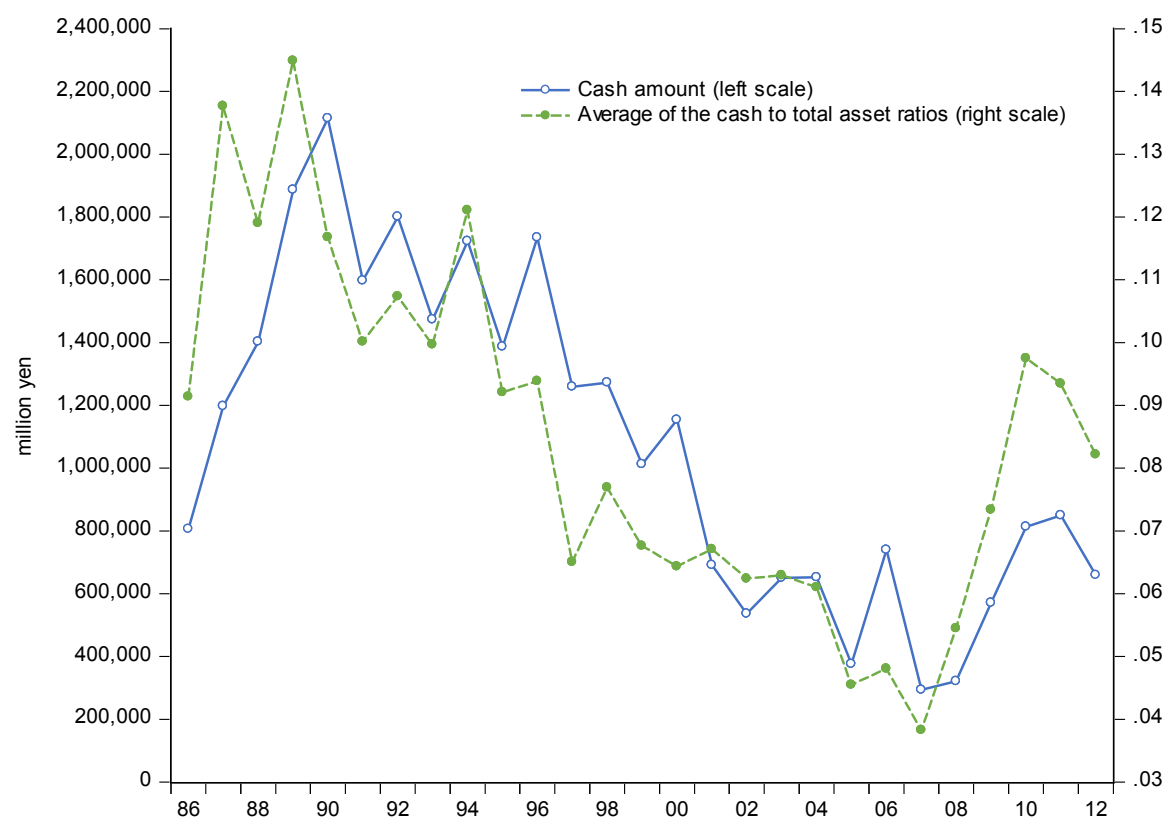

Figure 3. Time-series Dynamics of the Sum of Cash and the Average of the Cash to Total Asset Ratios: The Cases of the Automobile Related Firms in Japan

Notes: This figure shows the time-series dynamics of the cash amount and the average of the cash to total asset ratios of the Japanese automobile related companies. In this figure, the time-series of the sum of cash and the average of the cash to total asset ratios are from the fiscal year of 1985 to 2012.

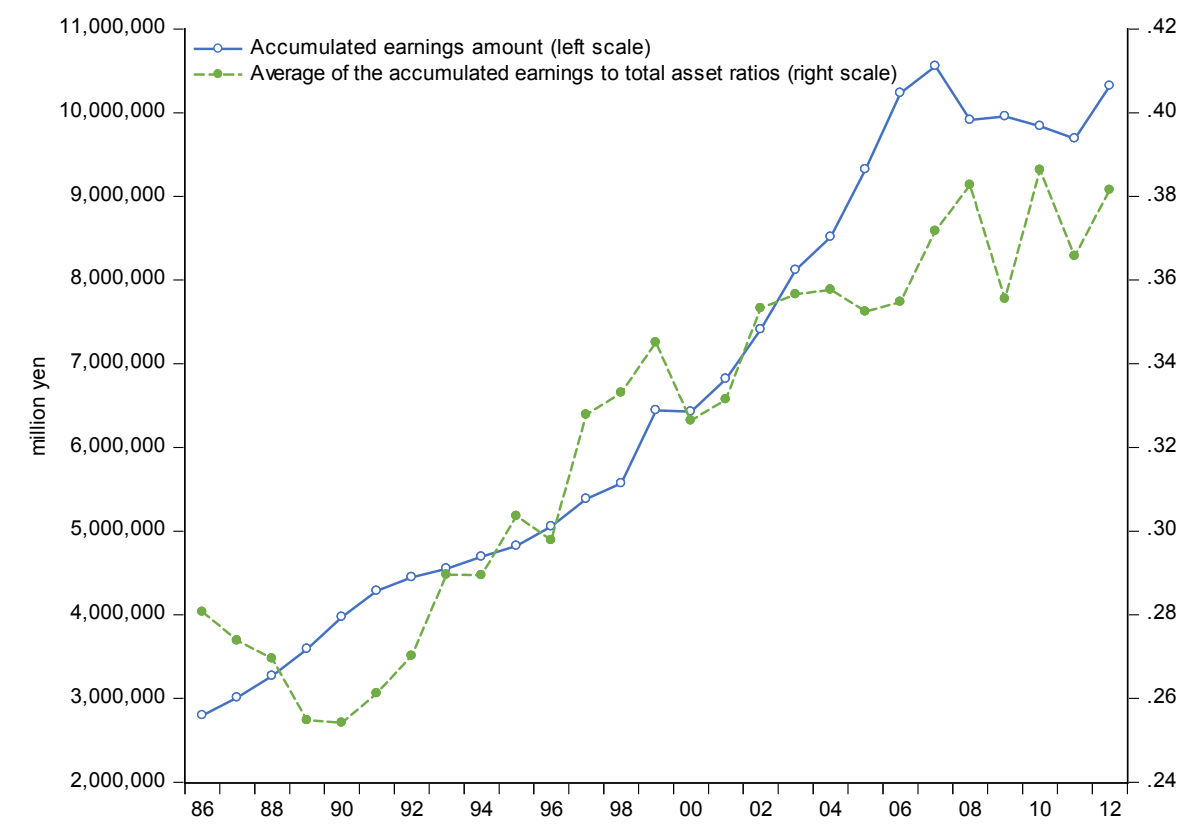

Figure 4. Dynamics of the Sum of Accumulated Earnings and the Average of the Accumulated Earnings to Total Asset Ratios: The Japanese Automobile Related Firms Cases.

Notes: This figure displays the time-series dynamics of the sum of accumulated earnings and the average of the accumulated earnings to total asset ratios of the Japanese automobile related companies. In this figure, the time-series of the sum of accumulated earnings and the average of the accumulated earnings to total asset ratios are from the fiscal year of 1985 to 2012 . 


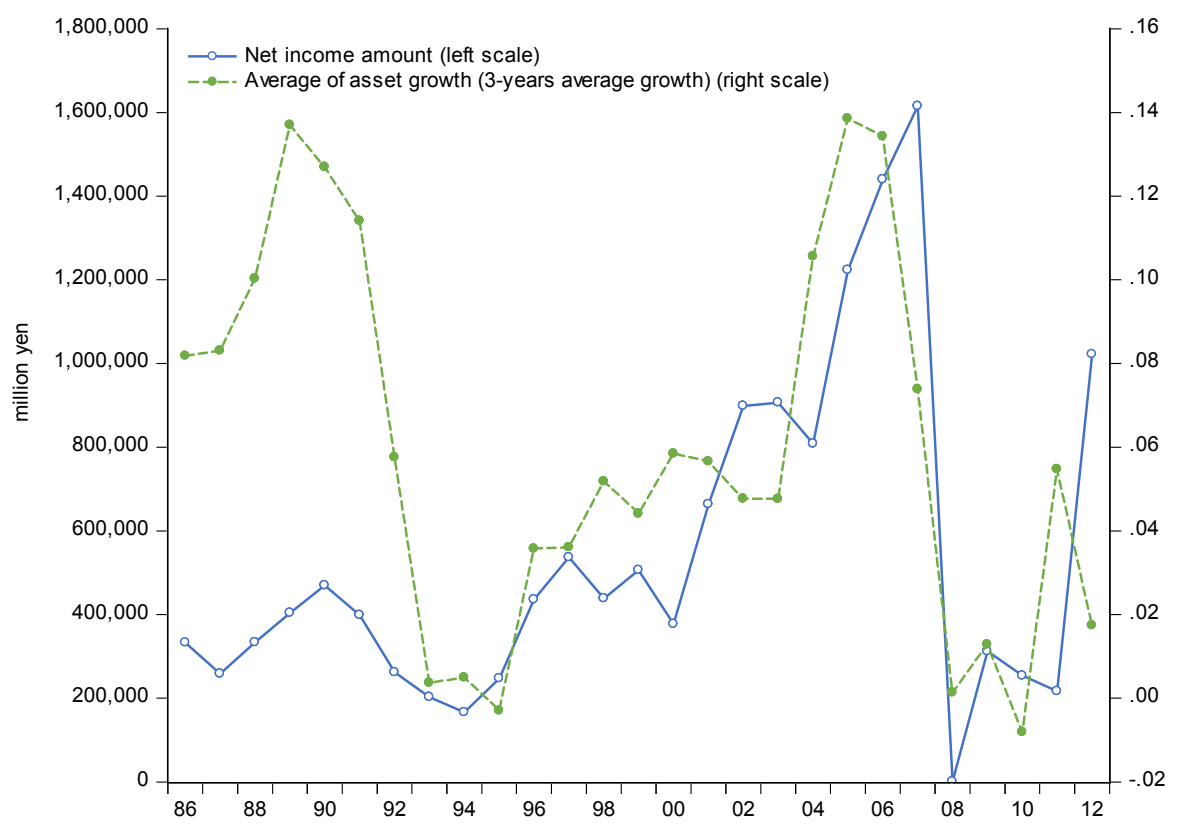

Figure 5. Time-series Dynamics of the Sum of Net Income and the Average of Asset Growth: The Cases of the Automobile Related Firms in Japan

Notes: This figure indicates the time-series dynamics of the sum of net income and the average of asset growth of the Japanese automobile related companies. In this figure, the time-series of the sum of net income and the average of asset growth are from the fiscal year of 1985 to 2012. Seventeen firms, which are categorized in the automobile related firms by the Nikkei Inc. in Japan, are analyzed in this paper.

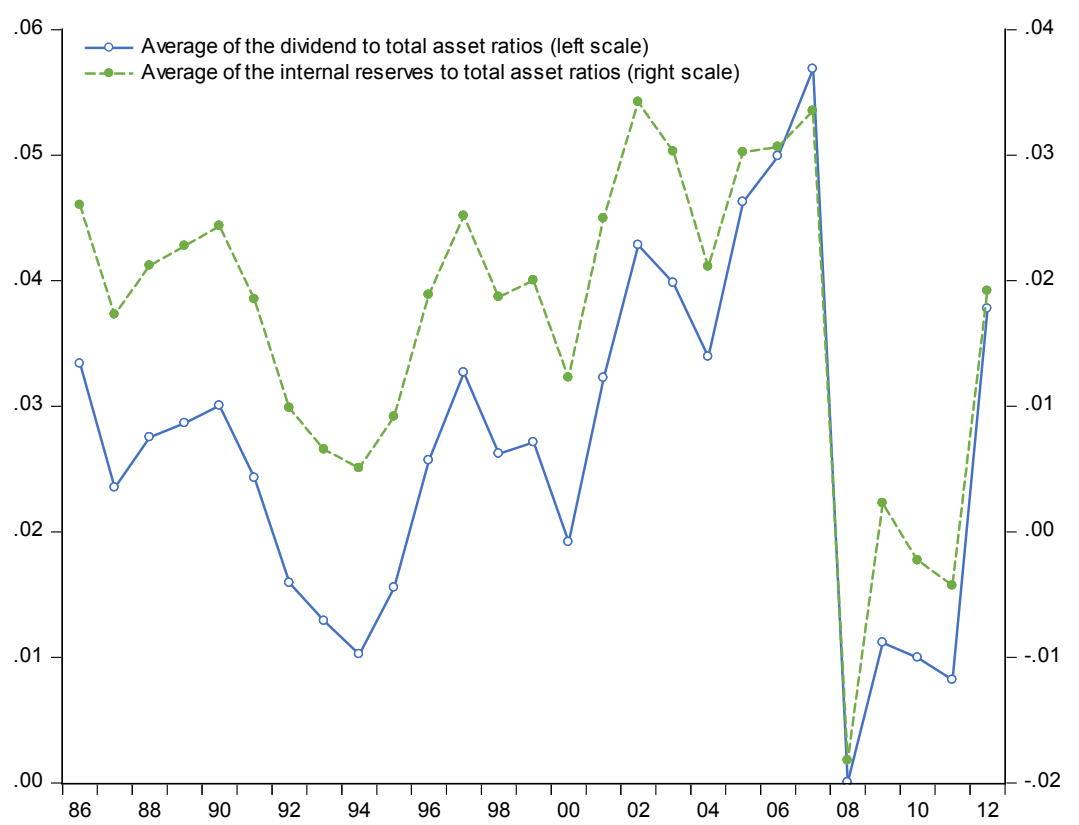

Figure 6. Dynamics of the Average of the Dividend to Total Asset Ratios and the Average of the Internal Reserves to Total Asset Ratios: The Japanese Automobile Related Firms Cases

Notes: This figure shows the time-series dynamics of the average of the dividend to total asset ratios and the average of the internal reserves to total asset ratios of the Japanese automobile related companies. In this figure, the time-series of the average of the dividend to total asset ratios and the average of the internal reserves to total asset ratios are from the fiscal year of 1985 to 2012. 


\section{Data and Variable Constructions}

The data utilized in this study are the balanced firm panel data of 17 firms. The sample period for our pooled regression analyses described later spans from 1986 to 2011 (26 fiscal years). Our focus is on the automobile related firms in Japan, whose data are available for constructing all variables analyzed in this study, and all data are supplied by the Quick Corp.

The concrete contents of the variables employed in our pooled regressions are as follows. First, RET denotes the one-year future stock return; CASH denotes the cash to total asset ratio; ACM means the accumulated earnings to total asset ratio; DIV is the dividend to total asset ratio; INTR is the internal reserves to total asset ratio; POR is the payout ratio; and PLBR denotes the plowback ratio. Further, SIZE denotes the firm size, which is measured by the market capitalization at the end of the fiscal year, and MB denotes the total market-value asset to total book-value asset ratio. Total market-value asset here is total book-value asset minus shareholders' equity (book-value) plus market capitalization of the firm.

\section{Research Design and Models}

Explaining our research design, we first overview the time-series dynamics of our main variables. We then also check the firm rankings according to the situation of our main variables from the cross-sectional viewpoint. Finally, we conduct the pooled regression analyses in order to clarify the states of market valuations of the firm cash holdings and the corporate dividend policies before and after the US Lehman shock.

In order to clarify the actual relation between the one-year future stock return and the corporate cash holdings or dividend policy variables, we use three kinds of panel regression models. The first is model (1), which includes a control variable of firm size, SIZE:

$$
R E T_{i, t+1}=\eta_{i, 0}+\eta_{i, 1} \Omega_{i, t}+\eta_{i, 2} S I Z E_{i, t}+v_{i, t+1} .
$$

The second model (2) includes a control variable of corporate market-to-book, MB:

$$
R E T_{i, t+1}=\xi_{i, 0}+\xi_{i, 1} \Omega_{i, t}+\xi_{i, 2} M B_{i, t}+\kappa_{i, t+1} .
$$

In models (1) and (2), $\mathrm{RET}_{i, t+1}$ denotes the one-year future stock return of firm $i$ in year $t+1$. Further, $\Omega_{i, t}$ represents each variable of CASH, ACM, DIV, INTR, POR, or PLBR. We note that our models (1) and (2) are rather simple; however, we consider that the simple models generally derive variable relations more robustly. We point out here that the size effects and the strong value effects seen in Tables 3 and 4 might hide the true relation between cash holdings and dividend policy variables and the one-year future stock return. Therefore, in order to scrutinize the one-to-one relationship between them, we employ the following model (3), which has no control variable as follows:

$$
R E T_{i, t+1}=\varsigma_{i, 0}+\varsigma_{i, 1} \Omega_{i, t}+\tau_{i, t+1}
$$

The notations of variables are the same as those in models (1) and (2). 


\section{Macrothink}

Table 1. Descriptive statistics for various variables related to cash, dividend payouts, and earnings retained of the automobile related firms in Japan: Statistics from the balanced panel data for the fiscal year from 1986 to 2011

\begin{tabular}{|c|c|c|c|}
\hline & CASH & $\mathrm{ACM}$ & DIV \\
\hline Mean & 0.0847 & 0.3210 & 0.0097 \\
\hline Median & 0.0704 & 0.2841 & 0.0083 \\
\hline Maximum & 0.2974 & 0.7641 & 0.0582 \\
\hline Minimum & 0.0013 & 0.0749 & 0.0017 \\
\hline Std. Dev. & 0.0638 & 0.1346 & 0.0063 \\
\hline Skewness & 0.8746 & 0.8498 & 3.4665 \\
\hline Kurtosis & 3.2039 & 3.1020 & 20.0326 \\
\hline Obs.(CS) & 17 & 17 & 17 \\
\hline Obs.(TS) & 26 & 26 & 26 \\
\hline \multirow[t]{2}{*}{ Obs.(Panel) } & 442 & 442 & 442 \\
\hline & INTR & POR & PLBR \\
\hline Mean & 0.0162 & 0.5430 & 0.3770 \\
\hline Median & 0.0138 & 0.3474 & 0.6287 \\
\hline Maximum & 0.0983 & 8.2996 & 0.9132 \\
\hline Minimum & -0.1205 & 0.0787 & -8.2996 \\
\hline Std. Dev. & 0.0222 & 0.7537 & 0.8660 \\
\hline Skewness & -0.8832 & 5.9188 & -5.0810 \\
\hline Kurtosis & 9.9148 & 47.6170 & 37.7063 \\
\hline Obs.(CS) & 17 & 17 & 17 \\
\hline Obs.(TS) & 26 & 26 & 26 \\
\hline \multirow[t]{2}{*}{ Obs.(Panel) } & 442 & 442 & 442 \\
\hline & SIZE & $\mathrm{MB}$ & RET \\
\hline Mean & 1.0699 & 1.4451 & 12.5460 \\
\hline Median & 0.0881 & 1.2886 & 4.7813 \\
\hline Maximum & 27.2555 & 9.7166 & 659.4394 \\
\hline Minimum & 0.0097 & 0.6529 & -73.7897 \\
\hline Std. Dev. & 3.1557 & 0.7097 & 50.8266 \\
\hline Skewness & 4.5508 & 5.0285 & 5.3069 \\
\hline Kurtosis & 27.0228 & 48.3399 & 62.0987 \\
\hline Obs.(CS) & 17 & 17 & 17 \\
\hline Obs.(TS) & 26 & 26 & 26 \\
\hline Obs.(Panel) & 442 & 442 & 442 \\
\hline
\end{tabular}

Notes: This table displays the descriptive statistics for various variables related to cash, dividend payouts, and earnings retained of the automobile related firms in Japan. The data are balanced panel data for the fiscal year from 1986 to 2011. In this table, 'Std. Dev.' means the standard deviation of variables. Further, 'Obs. (Panel)' indicates the number of the pooled data, 'Obs. (TS)' is the number of the time-series data, and 'Obs. (CS)' indicates the number of the cross-sectional data in each year. 
Table 2. The states of the firms ranked by the variables related to cash, dividend payouts, and earnings retained: The cases of the Japanese automobile related firms for 1986 to 2011

\begin{tabular}{|c|c|c|c|c|c|c|}
\hline & CASH & & $\mathrm{ACM}$ & & INTR & \\
\hline & Firm & Value & Firm & Value & Firm & Value \\
\hline 1 & Suzuki & 0.1581 & Toyota & 0.6072 & Toyota & 0.0305 \\
\hline 2 & Tachis & 0.1414 & Sanoh & 0.4926 & Honda & 0.0303 \\
\hline 3 & Sanoh & 0.1130 & Honda & 0.4625 & Sanoh & 0.0252 \\
\hline 4 & Toyota & 0.1108 & Exedy & 0.4081 & Exedy & 0.0249 \\
\hline 5 & Exedy & 0.1038 & Keihin & 0.3651 & Toyotab & 0.0208 \\
\hline 6 & Koito & 0.0953 & Toyotab & 0.3209 & Keihin & 0.0192 \\
\hline 7 & Toyoda & 0.0901 & Koito & 0.3196 & Toyoda & 0.0181 \\
\hline 8 & Keihin & 0.0811 & Aisan & 0.3155 & Koito & 0.0178 \\
\hline 9 & Honda & 0.0756 & Toyoda & 0.2942 & Tachis & 0.0142 \\
\hline 10 & Toyotab & 0.0754 & Aisin & 0.2870 & Aisin & 0.0136 \\
\hline 11 & Nok & 0.0752 & Pacific & 0.2750 & Aisan & 0.0117 \\
\hline 12 & Shiroki & 0.0745 & Trad & 0.2566 & Nok & 0.0115 \\
\hline 13 & Aisin & 0.0609 & Tachis & 0.2487 & Suzuki & 0.0109 \\
\hline 14 & Pacific & 0.0507 & Daihatsu & 0.2411 & Pacific & 0.0102 \\
\hline 15 & Daihatsu & 0.0486 & Nok & 0.2292 & Daihatsu & 0.0101 \\
\hline 16 & Aisan & 0.0452 & Suzuki & 0.1946 & Shiroki & 0.0043 \\
\hline \multirow[t]{3}{*}{17} & Trad & 0.0399 & Shiroki & 0.1386 & Trad & 0.0024 \\
\hline & POR & & MB & & RET & \\
\hline & Firm & Value & Firm & Value & Firm & Value \\
\hline 1 & Toyota & 0.9522 & Honda & 2.3261 & Toyoda & 34.4393 \\
\hline 2 & Nok & 0.7605 & Koito & 2.0404 & Toyotab & 18.8388 \\
\hline 3 & Trad & 0.7353 & Toyota & 1.8305 & Koito & 18.2285 \\
\hline 4 & Shiroki & 0.6854 & Nok & 1.7264 & Nok & 16.2063 \\
\hline 5 & Honda & 0.6107 & Toyotab & 1.6354 & Aisin & 12.2602 \\
\hline 6 & Toyoda & 0.5781 & Toyoda & 1.4772 & Tachis & 11.8884 \\
\hline 7 & Aisin & 0.5513 & Exedy & 1.4584 & Trad & 11.8530 \\
\hline 8 & Keihin & 0.5434 & Aisin & 1.4314 & Toyota & 11.3692 \\
\hline 9 & Pacific & 0.5109 & Suzuki & 1.3894 & Daihatsu & 11.1185 \\
\hline 10 & Aisan & 0.4814 & Keihin & 1.3345 & Exedy & 10.4593 \\
\hline 11 & Toyotab & 0.4740 & Daihatsu & 1.2526 & Honda & 10.3084 \\
\hline 12 & Sanoh & 0.4616 & Trad & 1.1805 & Pacific & 9.7993 \\
\hline 13 & Daihatsu & 0.4587 & Sanoh & 1.1678 & Keihin & 9.6414 \\
\hline 14 & Koito & 0.4312 & Shiroki & 1.1592 & Suzuki & 8.6593 \\
\hline 15 & Suzuki & 0.4260 & Pacific & 1.0932 & Aisan & 8.0413 \\
\hline 16 & Exedy & 0.2925 & Tachis & 1.0323 & Sanoh & 7.5614 \\
\hline 17 & Tachis & 0.2780 & Aisan & 1.0322 & Shiroki & 2.6099 \\
\hline
\end{tabular}

Notes: This table shows the firm rankings by the average values of the variables, CASH, ACM, INTR, POR, $\mathrm{MB}$, and RET. The firms are categorized in the automobile related firms by the Nikkei Inc. in Japan and the sample period is from the fiscal year of 1986 to 2011. The name of firms are as follows: Toyotab: Toyota Boshoku Corporation; Sanoh: Sanoh Industrial Co., Ltd.; Toyota: Toyota Motor Corporation; Trad: T. Rad Co., Ltd.; Tachis: Tachi-S Co., Ltd.; Nok: Nok Corporation; Shiroki: Shiroki Corporation; Pacific: Pacific Industrial Co., Ltd.; Keihin: Keihin Corporation; Aisin: Aisin Seiki Co., Ltd.; Daihatsu: Daihatsu Motor Co., Ltd.; Honda: Honda Motor Co., Ltd.; Suzuki: Suzuki Motor Corporation; Koito: Koito Manufacturing Co., Ltd.; Exedy: Exedy Corporation; Toyoda: Toyoda Gosei Co., Ltd.; Aisan: Aisan Industry Co., Ltd. 


\section{Time-series Overviews, Descriptive Statistics, and Rankings by Firm Characteristics}

This section surveys the several data before and after the US Lehman shock. First, Figure 1 exhibits the stock price dynamics of the US markets and two Japanese representative automobile firms for the period from January 1985 to November 2013. This figure indicates that after around 1990, the two Japanese leading automobile firms, Toyota and Honda, continuously underperform the S\&P 500 in the US. Moreover, after the Lehman shock of September 2008, the stock prices of Toyota and Honda further move behind the S\&P 500 .

Next, Figure 2 shows the time-series dynamics of the operating income to total asset ratios of Toyota and Honda. Figure 2 indicates that the after the Lehman shock, the operating income to total asset ratios of Toyota and Honda largely decrease. Further, the time-series dynamics of the sum of cash and the average of the cash to total asset ratios of seventeen automobile related firms in Japan are exhibited in Figure 3. This figure implies that the continuing downward trend of their cash holdings until the Lehman shock turns to the upward trend after the shock in September 2008.

Further, Figure 4 shows the dynamics of the sum of accumulated earnings and the average of the accumulated earnings to total asset ratios of seventeen Japanese automobile related firms. As this figure demonstrates, the generally continuing upward trend in the accumulated earnings in the Japanese automobile related firms is recognized. Moreover, Figure 5 displays the time-series dynamics of the sum of net incomes and the average of asset growth of the automobile related firms in Japan. This figure indicates that after the US Lehman shock, dynamics of the net income and the asset growth drop in the automobile related firms in Japan. Furthermore, the dynamics of the average of the dividend to total asset ratios and the average of the internal reserves to total asset ratios of seventeen Japanese automobile related firms are exhibited in Figure 6. This figure implies that after the Lehman shock, dynamics of the dividend payouts and the internal reserves also decline in the automobile related firms in Japan.

Next, we examine the states of our variables by checking the actual data; Table 1 displays the descriptive statistics for various variables related to cash, dividend payouts, and earnings retained of the automobile related firms in Japan. The statistics are computed by using the balanced panel data for the fiscal year from 1986 to 2011. Further, examining the company data by using the information in Table 2, when we focus on Toyota and Honda, first, not only the accumulated earnings (ACM) and internal reserves (INTR) but also the payout ratios (POR) of these two firms are relatively high. On the other hand, the stock returns (RET) of Toyota and Honda are not so high; this would be because their market-to-book ratios (MB) are already high: their stock prices are already evaluated in stock markets in Japan.

\section{Empirical Results and Interpretations}

This section documents our empirical results. First, we present the estimation results of our models (1) and (2) in Tables 3 and 4. More concretely, Table 3 displays the results for the period before the Lehman shock, while Table 4 exhibits the results for the period after the Lehman shock. 
Describing the results in short, first, Panel A of Table 3 shows that when including the firm size as a controlling variable, only the internal reserves to total asset ratio (INTR) is statistically significantly related with the one-year future stock return with negative sign. However, Panel B of Table 3 shows that when including the market-to-book ratio (MB) as a controlling variable, no explanatory variable is statistically significantly related with the one-year future return.

Next, Panel A of Table 4 shows that when including the firm size as a controlling variable, the cash to total asset ratio (CASH) is statistically significantly negatively related with the one-year future stock return. Further, the internal reserves to total asset ratio (INTR) is statistically significantly negatively related with the one-year future return. In addition, the payout ratio (POR) is statistically significantly positively related with the one-year future return. Furthermore, the plowback ratio (PLBR) is statistically significantly negatively related with the one-year future return. Moreover, Panel B of Table 4 demonstrates that when including the market-to-book ratio (MB) as a controlling variable, in addition to the same relations as to the above four variables, the dividend to total asset ratio (DIV) shows the statistically significant positive relation with the one-year future return. Namely, different control variables derive the slightly different results; we thus consider that control variables might hide the true relationship between each explanatory variable and the one-year future stock return.

In order to exclude the control variable effects, we then investigate the variable relations without any control variables and display the results in Table 5. Panel A of Table 5 shows the results for the period from the fiscal year of 1986 to 2007, while Panel B displays the results for the period from the fiscal year of 2008 to 2011. Panel A of Table 5 exhibits that only the internal reserves to total asset ratio (INTR) is statistically significantly negatively related with the one-year future return. Differently from this result, Panel B of Table 5 indicates that the payout ratio (POR) is statistically significantly related with the one-year future stock return with positive sign. Furthermore, the cash to total asset ratio (CASH), the internal reserves to total asset ratio (INTR), and the plowback ratio (PLBR) are statistically significantly negatively related with the one-year future return in the panel.

An interpretation of these results shows that, after the Lehman shock, the firms, which implemented dividend payouts regardless of the difficult economic condition, were evaluated in equity markets; contrary, it is considered that the firms, which retained and accumulated their earnings and maintained their high cash holdings, were not evaluated in stock markets. Although these are the short-term stock market valuations, our results statistically strongly show that after the US Lehman shock, the firms which maintained their payouts without retaining their earnings were evaluated in equity markets. We consider that these results would show the investors' stronger requirements for payouts as the result of the hard economic condition in the period after the Lehman shock. We could also conjecture that after the Lehman shock, investors' evaluations of corporate payout policies would become more myopic due to the harsh economic environment. Moreover, as for a further interpretation, when the economic condition is harder, investors more prefer the tough firms which can maintain shareholders' utility by keeping up their payouts to shareholders. 
Table 3. Results of panel data analyses with control variables: Evidence for the fiscal year from 1986 to 2007

Panel A. Results of the pooled regressions with the control variable of firm size

\begin{tabular}{|c|c|c|c|c|c|c|}
\hline & Model 1 & Model 2 & Model 3 & Model 4 & Model 5 & Model 6 \\
\hline Constant & $9.4146 * *$ & 12.3509 & $16.9825 * * *$ & $16.9585^{* * *}$ & 6.4317 & $16.7912 * * *$ \\
\hline$p$-value & 0.0406 & 0.1264 & 0.0021 & 0.0000 & 0.1948 & 0.0004 \\
\hline $\mathrm{CASH}$ & 23.9147 & & & & & \\
\hline$p$-value & 0.5691 & & & & & \\
\hline $\mathrm{ACM}$ & & -3.1372 & & & & \\
\hline$p$-value & & 0.9048 & & & & \\
\hline DIV & & & -670.6557 & & & \\
\hline$p$-value & & & 0.2386 & & & \\
\hline INTR & & & & $-334.6577 * *$ & & \\
\hline$p$-value & & & & 0.0246 & & \\
\hline POR & & & & & 12.1337 & \\
\hline$p$-value & & & & & 0.2147 & \\
\hline PLBR & & & & & & -10.1893 \\
\hline$p$-value & & & & & & 0.1479 \\
\hline SIZE & -0.6554 & -0.5708 & -0.0490 & 0.0660 & -0.5570 & -0.5189 \\
\hline$p$-value & 0.4450 & 0.5880 & 0.9607 & 0.9421 & 0.5167 & 0.5462 \\
\hline $\operatorname{Adj} . R^{2}$ & -0.0030 & -0.0038 & -0.0001 & 0.0097 & 0.0003 & 0.0018 \\
\hline
\end{tabular}

Panel B. Results of the pooled regressions with the control variable of market to book ratio

\begin{tabular}{|c|c|c|c|c|c|c|}
\hline & Model 1 & Model 2 & Model 3 & Model 4 & Model 5 & Model 6 \\
\hline Constant & $22.5226^{* * *}$ & $25.4749 * * *$ & $26.2355^{* * *}$ & $26.3774 * * *$ & $20.7661^{* * *}$ & $28.5529 * * *$ \\
\hline$p$-value & 0.0007 & 0.0023 & 0.0001 & 0.0000 & 0.0069 & 0.0000 \\
\hline CASH & 41.2726 & & & & & \\
\hline$p$-value & 0.3270 & & & & & \\
\hline $\mathrm{ACM}$ & & -0.9093 & & & & \\
\hline$p$-value & & 0.9663 & & & & \\
\hline DIV & & & -206.7384 & & & \\
\hline$p$-value & & & 0.6956 & & & \\
\hline INTR & & & & -228.1055 & & \\
\hline$p$-value & & & & 0.1237 & & \\
\hline POR & & & & & 9.2524 & \\
\hline$p$-value & & & & & 0.3430 & \\
\hline PLBR & & & & & & -7.9395 \\
\hline$p$-value & & & & & & 0.2589 \\
\hline MB & $-10.2939 * * *$ & $-9.7121 * * *$ & $-9.1375^{* *}$ & $-7.6413 * *$ & $-9.2619 * *$ & $-9.1041 * *$ \\
\hline$p$-value & 0.0053 & 0.0089 & 0.0211 & 0.0489 & 0.0118 & 0.0135 \\
\hline $\operatorname{Adj} . R^{2}$ & 0.0163 & 0.0137 & 0.0142 & 0.0200 & 0.0161 & 0.0171 \\
\hline
\end{tabular}

Notes: In this table, Adj. $R^{2}$ is the adjusted $R$-squared value. Further, *** indicates the statistical significant coefficients at the $1 \%$ level, $* *$ indicates the statistical significant coefficients at the $5 \%$ level, and $*$ indicates the statistical significant coefficients at the $10 \%$ level, respectively. 
Table 4. Results of panel data analyses with control variables: Evidence for the fiscal year from 2008 to 2011

Panel A. Results of the pooled regressions with the control variable of firm size

\begin{tabular}{|c|c|c|c|c|c|c|}
\hline & Model 1 & Model 2 & Model 3 & Model 4 & Model 5 & Model 6 \\
\hline Const. & $42.7405 * * *$ & 17.9508 & $22.3244 * * *$ & $26.5613 * * *$ & $16.2247 * * *$ & $22.0010 * * *$ \\
\hline$p$-value & 0.0000 & 0.1829 & 0.0076 & 0.0000 & 0.0058 & 0.0000 \\
\hline $\mathrm{CASH}$ & $-217.6143^{* *}$ & & & & & \\
\hline$p$-value & 0.0122 & & & & & \\
\hline $\mathrm{ACM}$ & & 17.1391 & & & & \\
\hline$p$-value & & 0.6452 & & & & \\
\hline DIV & & & 124.7520 & & & \\
\hline$p$-value & & & 0.8333 & & & \\
\hline INTR & & & & $-630.0586^{* *}$ & & \\
\hline$p$-value & & & & 0.0000 & & \\
\hline POR & & & & & $7.6885^{* *}$ & \\
\hline$p$-value & & & & & 0.0177 & \\
\hline PLBR & & & & & & $-8.3706^{* * *}$ \\
\hline$p$-value & & & & & & 0.0027 \\
\hline SIZE & -2.5573 & -1.6889 & -1.3204 & -2.1179 & $-3.2007^{*}$ & $-3.2184 * *$ \\
\hline$p$-value & 0.1120 & 0.3906 & 0.4582 & 0.1272 & 0.0672 & 0.0488 \\
\hline $\operatorname{Adj} . R^{2}$ & 0.0726 & -0.0190 & -0.0216 & 0.2329 & 0.0630 & 0.1109 \\
\hline
\end{tabular}

Panel B. Results of the pooled regressions with the control variable of market to book ratio

\begin{tabular}{|c|c|c|c|c|c|c|}
\hline & Model 1 & Model 2 & Model 3 & Model 4 & Model 5 & Model 6 \\
\hline Const. & $78.2972 * * *$ & $57.0779 * * *$ & $76.8306^{* * *}$ & $60.0091 * * *$ & $60.6096 * * *$ & $63.7003 * * *$ \\
\hline$p$-value & 0.0000 & 0.0003 & 0.0000 & 0.0000 & 0.0000 & 0.0000 \\
\hline $\mathrm{CASH}$ & $-173.9237 * *$ & & & & & \\
\hline$p$-value & 0.0235 & & & & & \\
\hline $\mathrm{ACM}$ & & 43.6189 & & & & \\
\hline$p$-value & & 0.1567 & & & & \\
\hline DIV & & & $1882.3790 * * *$ & & & \\
\hline$p$-value & & & 0.0046 & & & \\
\hline INTR & & & & $-556.9808 * *$ & & \\
\hline$p$-value & & & & 0.0001 & & \\
\hline POR & & & & & $6.1494 * *$ & \\
\hline$p$-value & & & & & 0.0218 & \\
\hline PLBR & & & & & & $-6.8040 * * *$ \\
\hline$p$-value & & & & & & 0.0045 \\
\hline MB & $-34.2462 * * *$ & $-41.4647 * * *$ & $-63.4220 * * *$ & $-29.4294 * * *$ & $-37.6088 * * *$ & $-36.4256 * * *$ \\
\hline$p$-value & 0.0019 & 0.0010 & 0.0000 & 0.0036 & 0.0008 & 0.0008 \\
\hline $\operatorname{Adj} . R^{2}$ & 0.1693 & 0.1280 & 0.2058 & 0.3024 & 0.1709 & 0.2060 \\
\hline
\end{tabular}

Notes: In this table, Adj. $R^{2}$ is the adjusted $R$-squared value. Further, *** indicates the statistical significant coefficients at the $1 \%$ level, $* *$ indicates the statistical significant coefficients at the $5 \%$ level, and $*$ indicates the statistical significant coefficients at the $10 \%$ level, respectively. 


\section{Macrothink}

Journal of Social Science Studies

ISSN 2329-9150

2014, Vol. 1, No. 2

Table 5. Results of the panel data analyses without control variable: Evidence for the fiscal year from 1986 to 2007 and the fiscal year from 2008 to 2011

Panel A. Panel data analyses without controlling variables: Evidence from the pooled regressions for the period from 1986 to 2007

\begin{tabular}{|c|c|c|c|c|c|c|}
\hline & Model 1 & Model 2 & Model 3 & Model 4 & Model 5 & Model 6 \\
\hline Const. & $8.7962 *$ & $14.3283 * *$ & $17.0620 * * *$ & $16.9574 * * *$ & 5.6419 & $16.4795 * * *$ \\
\hline$p$-value & 0.0518 & 0.0468 & 0.0013 & 0.0000 & 0.2402 & 0.0004 \\
\hline $\mathrm{CASH}$ & 23.1653 & & & & & \\
\hline$p$-value & 0.5810 & & & & & \\
\hline $\mathrm{ACM}$ & & -11.3914 & & & & \\
\hline$p$-value & & 0.5936 & & & & \\
\hline DIV & & & -684.8757 & & & \\
\hline$p$-value & & & 0.1621 & & & \\
\hline INTR & & & & $-330.9217^{* *}$ & & \\
\hline$p$-value & & & & 0.0177 & & \\
\hline POR & & & & & 12.6500 & \\
\hline$p$-value & & & & & 0.1940 & \\
\hline PLBR & & & & & & -10.6154 \\
\hline$p$-value & & & & & & 0.1295 \\
\hline $\operatorname{Adj} . R^{2}$ & -0.0019 & -0.0019 & 0.0026 & 0.0124 & 0.0019 & 0.0035 \\
\hline
\end{tabular}

Panel B. Panel data analyses without controlling variables: Evidence from the pooled regressions for the period from 2008 to 2011

\begin{tabular}{|c|c|c|c|c|c|c|}
\hline & Model 1 & Model 2 & Model 3 & Model 4 & Model 5 & Model 6 \\
\hline Const. & $35.8698 * * *$ & $23.0521^{*}$ & $23.2847 * * *$ & $23.8785^{* * *}$ & $16.0462 * * *$ & $19.1778 * * *$ \\
\hline$p$-value & 0.0000 & 0.0577 & 0.0047 & 0.0000 & 0.0072 & 0.0001 \\
\hline $\mathrm{CASH}$ & $-170.7372 * *$ & & & & & \\
\hline$p$-value & 0.0369 & & & & & \\
\hline $\mathrm{ACM}$ & & -2.1117 & & & & \\
\hline$p$-value & & 0.9432 & & & & \\
\hline DIV & & & -81.5188 & & & \\
\hline$p$-value & & & 0.8759 & & & \\
\hline INTR & & & & $-598.1319 * *$ & & \\
\hline$p$-value & & & & 0.0000 & & \\
\hline POR & & & & & $4.7984^{*}$ & \\
\hline$p$-value & & & & & 0.0916 & \\
\hline PLBR & & & & & & $-6.1382 * *$ \\
\hline$p$-value & & & & & & 0.0166 \\
\hline $\operatorname{Adj} . R^{2}$ & 0.0502 & -0.0151 & -0.0148 & 0.2168 & 0.0280 & 0.0700 \\
\hline
\end{tabular}

Notes: In this table, Adj. $R^{2}$ is the adjusted $R$-squared value. Further, for judging the statistical significance of parameters, $* * *$ indicates the statistical significant coefficients at the $1 \%$ level, $* *$ indicates the statistical significant coefficients at the $5 \%$ level, and * indicates the statistical significant coefficients at the $10 \%$ level, respectively. Panel A shows the results for the period before the US Lehman shock, while Panel B shows the results for the period after the US Lehman shock. 


\section{Summary and Conclusions}

This paper investigated the relationship between the corporate dividend policies and their stock returns and also the linkage between the firm cash holdings and their stock returns. In our analyses, we used the data of the automobile related firms at the TSE by focusing on the two periods, before and after the US Lehman shock.

Summarizing the findings from our studies, first, (1) before the US Lehman shock, only the corporate internal reserves to total asset ratio was related with the one-year future stock return. Second, (2) after the US Lehman shock, the cash to total asset ratio, the internal reserves to total asset ratio, the payout ratio, and the plowback ratio were always statistically significantly related with the one-year future stock return regardless of the control variables inclusions.

We note that in this study, our focus was on the short-term firm valuation for one-year future time period, thus our results do not tell us about the middle- or long-term firm performance affected by their policies of payout and cash holdings. This might be the limitation of our study; this is mainly because of the data availability. However, we again emphasize that regarding the linkage among corporate cash holdings, dividend policies, and their one-year future stock returns, we derived the statistically strong and very clear evidence for the period after the US Lehman shock; this demonstrates the strong contribution of this study.

Nevertheless, the investigations of the middle-term or long-term future firm valuation focusing on the corporate dividend and cash holding policies are also interesting. We consider that this shall be one of our future tasks after waiting for the data accumulation.

\section{Acknowledgement}

I thank the Japan Society for the Promotion of Science for their kind financial support for my research. Further, I also thank the Editor and the anonymous referees for their kind comments to this paper. Finally, I greatly thank the repeated kind invitation from the journal to write to this journal.

\section{References}

Al-Najjar, B., \& Belghitar, Y. (2011). Corporate cash holdings and dividend payments: evidence from simultaneous analysis. Managerial and Decision Economics, 32, 231-241. http://dx.doi.org/10.1002/mde.1529

Faulkender, M., \& Wang, R. (2006). Corporate financial policy and the value of cash. Journal of Finance, 61, 1957-1990. http://dx.doi.org/10.1111/j.1540-6261.2006.00894.x

Harford, J., Mansi, S. A., \& Maxwell, W. F. (2008). Corporate governance and firm cash holdings in the US. Journal of Financial Economics, 87, 535-555. http://dx.doi.org/10.1016/j.jfineco.2007.04.002

Jensen, M. C. (1986). Agency Cost of free cash flow, corporate finance, and takeovers. American Economic Review, 76, 323-329. http://dx.doi.org/10.2139/ssrn.99580 
Miller, M. H. \& Modigliani, F. (1961). Dividend policy, growth, and the valuation of shares. Journal of Business, 34, 411-433.

Pinkowitz, L., Stulz, R., \& Williamson, R. (2006). Does the contribution of corporate cash holdings and dividends to firm value depend on governance? A cross-country analysis. Journal of Finance, 61, 2725-2751. http://dx.doi.org/10.1111/j.1540-6261.2006.01003.x

\section{Copyright Disclaimer}

Copyright reserved by the author(s).

This article is an open-access article distributed under the terms and conditions of the Creative Commons Attribution license (http://creativecommons.org/licenses/by/3.0/). 